\title{
Immunological response in congenital cytomegalovirus infection
} Elio Freda*1, Maria Luisa Romiti ${ }^{1}$, Giusy LiPira ${ }^{2}$, Fabio Casciano ${ }^{1}$, Alessandra Simonetti ${ }^{3}$, Fabrizio Manca ${ }^{4}$, Andrzej Krzysztofiak ${ }^{3}$, Paolo Rossi ${ }^{1,3}$, Patrizia D' Argenio ${ }^{3}$ and Caterina Cancrini ${ }^{1,3}$

Address: ${ }^{1}$ Cattedra di Pediatria, Università di Roma Tor Vergata, Roma, Italia, ${ }^{2}$ Cellular Immunology Unit, Advanced Biotechnology Center, Genova, Italia, ${ }^{3}$ U.O.C. di Immuno-Infettivologia Ospedale Pediatrico Bambino Gesù, Roma, Italia and ${ }^{4}$ Clinical and Experimental Immunology Laboratory, G. Gaslini Institute, Genova, Italia

* Corresponding author

from Fourth Dominique Dormont International Conference. Host-Pathogen Interactions in Chronic Infections Paris, France. 13-15 December 2007

Published: 9 April 2008

Retrovirology 2008, 5(Suppl I):P20 doi:I0.1 186/I742-4690-5-SI-P20

This abstract is available from: http://www.retrovirology.com/content/5/SI/P20

(c) 2008 Freda et al.; licensee BioMed Central Ltd.

\section{Background}

Human cytomegalovirus (CMV) is the main cause of congenital viral infection. There are not early and certain prognostic markers to define infection / disease course and no standard treatment of children with symptomatic congenital infection is available as yet. Indeed, a small number of infants present severe neurological complications and isolated visual and hearing impairments. The aim of our study is to verify possible correlations between immunologic alterations and clinical/ therapeutic aspects. Eighteen eligible infants were enrolled in our study. Eight of them were symptomatic, showing neurological alterations.

\section{Methods}

Lymphocyte proliferation was detected by co-culture with mitogens (Phytohemagglutinin and Pokeweed), antiCD3 monoclonal antibody, recall (Candida) and CMVspecific antigens. T-cell receptor (TCR) repertoire of CD8+ and CD4+ T-cell subsets was analysed by Spectratyping after RNA extraction and cDNA synthesis and amplification with a SuperScript One-Step RT-PCR kit (Invitrogen) by 24 different $V \beta$ primers combination with a 3' $\mathrm{C} \beta$ labelled primer. IFN- $\gamma$ production after CMV lisate and peptides pool stimulation was evaluated by cellELISA in 384 wells microplates.

\section{Results}

Standard immunological investigations as immunoglobulins levels and cellular immunity did not show any alteration in both groups. All symptomatic patients (8/8) did not show any specific CMV response in lymphoproliferative assay. Six out of ten asymptomatic patients showed a good CMV specific response (Stimulation Index > 3). TCR spectratyping analysis on CD8 T-cell subset showed a various degree of alteration in all symptomatic patients and in six out of nine analysed asymptomatic patients. CellELISA assay on CD4 and CD8 T-cell subset was performed and the evaluation of results is ongoing.

\section{Conclusions}

Our preliminary data suggest a possible correlation between a lack of $\mathrm{CMV}$ specific response and higher degree alteration of TCR spectratyping analysis in symptomatic versus asymptomatic patients. 